\title{
La Controversia Literaria Sobre "Las Ruinas de Pachacamac", Lima, 1822
}

$\mathcal{A}^{\mathrm{L}}$ diez de enero de mil ochocientos veintidós expidió el Protector del 1. Perú, general José de San Martín, un Decreto, refrendado por su ministro Bernardo de Monteagudo, fundando en Lima una Sociedad Patriótica "compuesta de los hombres más ilustrad'os, que reuniéndose bajo la especial protección del gobierno, discuta todas las materias que pueden influir en la mejora de nuestras instituciones, publicando sobre ellas memorias que cada miembro presente, según la profesión a que pertenezca".* El articulado del propio Decreto dispuso que dicho "establecimiento literario" había de componerse de cuarenta miembros y celebrar sesiones los martes y viernes de cada semana "para discutir todas las cuestiones que tengan un influjo directo o indirecto sobre el bien público, sean en materias políticas, económicas o científicas." De acuerdo con el subsiguiente Reglamento de la Sociedad Patriótica, aprobado el veinte de febrero del mismo año de mil ochocientos veintidós, los cuarenta "académicos ordinarios" se repartían en cuatro secciones: de Agricultura, Artes y Comercio, la primera; de Ciencias físicas y matemáticas, la segunda; de Filosofía especulativa, la tercera; y la cuarta, de Bellas Letras, que com-

* Trabajo presentadó al grupo de Literatura Hispanoamericana de la Modern Language Association of America, en Filadelfia, Pennsylvania, el 28 de diciembre de 1960. Agradezco al Joint Committee on Latin American Studies del American Council of Learned Societies y del Social Science Research Council, la subvención que me concedió para que el verano de 1960 viajara a Lima, donde recogí -entre otros- los materiales básicos del presente estudio. 
prendían las Antigüedades, la Historia, la Lengua, la Poesia y la Oratoria. La sección cuarta había de reunirse el cuarto martes de cad'a mes. ${ }^{1}$

Según se lee en las actas de las sesiones de la Sociedad Patriótica, ${ }^{2}$ ésta acordó publicar, además de las memorias, un periódico semanal bajo nombre de El Sol del Perú, cuyo primer número apareció el catorce de marzo de mil ochocientos veintidós. ${ }^{3}$

Los historiadores suelen estar de acuerdo en creer que Monteagudo decidió establecer la Sociedad Patriótica de Lima para, so capa de discusiones teóricas sobre los sistemas de gobierno, promover su plan de establecer en el Perú un gobierno monárquico, bajo la égida de un príncipe europeo, o por lo menos un gobierno con un poder ejecutivo muy fuerte. Cierto es que en la sesión del veintidós de febrero, Monteagudo como presidente de la Sociedad propuso a ésta como primer asunto para su consideración, el siguiente: “¿Cuál es la forma de gobierno más adaptable al Estado peruano, según su extensión, población, costumbres y grado que ocupa en la escala de la civilización?" $Y$ no menos cierto es que las sesiones más movidas fueron las dedicadas a este tema. En ellas varios miembros defendieron el sistema monárquico pero en cambio otros se atrevieron, no obstante la evidente parcialidad de los directores, a defender el sistema republicano. Y finalmente, cierto es también que expulsado Monteagudo del poder, la Sociedad Patriótica dejó de funcionar.

Sea de ello lo que fuere y a pesar del carácter primordialmente político de esta entidad y de sus publicaciones, lo que a nosotros nos interesa aquí es un artículo aparecido en el primer número de El Sol del Perú que, aunque tiene implicaciones políticas (inevitables dado el momento), es ante todo una pieza esencialmente literatia que dio ocasión a una controversia también esencialmente literaria, de interés para la historia del pensamiento estético en el Perú.

En efecto, en dicho No. I de El Sol del Perú, de I4 de marzo de I822, págs. 2 a 4, aparece un trozo titulado "Las Ruinas de Pachacamac",

1 Ver dichos Decreto y Reglamento en Manuel de Odriozola, Documentos literarios del Perú (Lima, 1877), XI, págs. 489-495.

2 Dichas actas pueden verse impresas en Odriozola, Documentos literarios, XI, págs. 417.488 .

3 He manejado la colección de El Sol del Perí existente en la Biblioteca Nacional del Perú, Lima, que comprende diez números, desde el $1^{\circ}$, de 14 de marzo de 1822 , al $10^{\circ}$, de 27 de junio de 1822 .

* Odriozola, Documentos literarios, XI, pág. 420. 
firmado con las iniciales "F. D." (Ver su texto en el Anejo No. I a este trabajo). A dicho artículo se refiere otro, impreso en el No. 21 , de 6 die abril de I822, del Correo Mercantil, Político y Literario, de Lima, págs. 2 y 3, titulado "Artículo comunicado. Carta escrita de Lunaguaná al editor con fecha 28 de marzo", firmado con el seudónimo "Justo Agrícola" (Ver su texto en el Anejo No. 2 a este trabajo). "A él contestó el autor del primero con otro titulado "Respuesta al Censor de las Ruinas de $\mathrm{Pa}$ chacamac" publicado en El Sol del Peruí, No. 4, de I2 de abril de I822, págs. 3-4. Al reimprimirse en el Correo Mercontil, Politico y Literario, No. 23 , de 24 de abril de 1822 , págs. 2-5, como "Artículo remitido" dicha "Respuesta" fue ésta "ilustrada con notas" polémicas y censorias (Ver el texto de la "Respuesta" que es exactamente igual en El Sol, No. 4, y el Correo, No. 23, y el de las "notas" de dicho Correo, No. 23, en el Anejo No. 3 a este trabajo).

\section{III}

El autor de "Las Ruinas de Pachacamac", que las firma con las iniciales "F. D.", es sin duda Félix Devoti. En efecto, el artículo I2 del Decreto de San Martín d'e ro de enero de 1822 expresa los nombres de los que serán los cuarenta miembros fundadores de la Sociedad Patriótica y entre ellos figura el del "Dr. D. Félix Devoti."6 En el Reglamento de 27 de enero, en la distribución de socios, aparece asignado a la sección cuarta (Bellas Letras) el propio Devoti. 7 En el No. 6 de El Sol del Perú, de 25 de abril de I822, pág. 4, figura igualmente Devoti en la lista de miembros y en la sección cuarta. Es más, en la sesión de la Sociedad' Patriótica del 25 de febrero "fueron elegidos, para que corriese a su cargo la edición del periódico semanal, los señores López Aldana, Cavero, Devoti y Salia" y "El Sr. Devoti quedó encargado de dar a luz el lunes 4 de marzo, el prospecto del referido periódico semanal." 8 En la sesión del I4 de junio, "los señores Arce y Paredes (D. Joaquín) fueron encargadlos con D. Félix Devoti de la edición del periódico del Sol"s. Es decir, que Félix Devoti fue, del principio al fin de la existencia de El Sol del Perú,

5 He manejado la colección del Correo Mercatuil, Politico y Literario conservada en la Biblioteca Nacional, de Lima, y que comprende desde el $\mathrm{N}^{0} 1$, del tomo I, de 19 de diciembre de 1821, hasta el $\mathrm{N}^{\circ} 29$ del tomo II, de 31 de diciembre de 1823 .

6 Odriozola, Documentos literarios, XI, pág. 491.

7 Ibíd., XI, pág. 495.

8 . Ibid., XI, pág. 421.

9 Ibíd., XI., pág. 448. 
uno de los editores del mismo. Las actas de las sesiones comprueban igualmente sus demás actividades - discursos, memorias, encargos- en la Sociedad Patriótica. ${ }^{10}$ Finalmente, no figura en ella otro miembro, entre los cuarenta fundadores, cuyas iniciales sean F. D.

Nació Félix Devoti en Roma, de una familia que, como él mismo dice, "si no es de las más distinguidas, no es de las últimas", 11 y era hermano de Giovanni Devoti (I744:I820), canonista, catedrático de la Sapienza a los veinte años, obispo de Agnani veinticinco años después $y$, desde 1804 , arzobispo titular de Cartago, "reputado por uno de los primeros literatos de Italia". ${ }^{12}$

Declara D. Félix haber llegado al continente americano, por vía de Jamaica, a Cartagena de Indias en el tiempo de las expediciones al Darién, en las que sirvió como director de hospitales. Marchó después a Santa Fe de Bogotá en donde fue primer médico del hospital general y después a Popayán con igual destino. De allí pasó a Quito y "permaneció en él mucho tiempo", siguiendo después hasta Lima. Medina anota que Devoti había ejercido su profesión de médico en Santa Fe y Trujillo desde

10 Ibid., XI., pág. 418, firma Félix Devoti en duodécimo lugar el acta de la sesión inaugural de la Sociedad Patriótica el 20 de enero de 1822; págs. 435-436, resumen de la Memoria que leyó sobre la forma de gobierno que convendría al Perú, en la sesión de 15 de marzo; pág. 449, el Presidente encarga a Devoti y a Arce que continúen la discusión interrumpida sobre el amor a la patria; pág. 450, en la sesión de 29 de junio, discurso de Devoti sobre los principales acontecimientos de la revolución del Perú desde que el Ejército Libertador desembarcó en Pisco hasta el momento.

11 "Un romance desmentido", Nuevo Día del Perú, Trujillo, N 3,15 de julio de 1824. Este artículo es una apología pro vita sua, con noticias biográficas. Luis Alayza Paz Soldán en su ob:a Unanue, Satn Martín y Bolivar (Lima, 1934), págs. $307-400$, transcribe el texto de la colección completa (12 números) del Nuevo Día del Perú, periódico publicado en Trujillo del $1^{\circ}$ de julio al 25 de septiembre de 1824 por Hipólito Unanue y Félix Devoti. Ambos, con otros patriotas peruanos, hubieron de refugiarse alli, huidos de Lima, reocupada por las fuerzas realistas el 27 de febrero de dicho año, meses antes de Junín y Ayacucho. "Un romance desmentido" se halla a las págs. 324-325 del libro de Alayza. Otras noticias biográficas de Félix Devoti pueden verse en un memorial y una carta suyas que José Toribio Medina encontró en el Archivo de Indias, de Sevilla, y publicó en La imprenta en Lima (1584-1824) (Santiago de Chile, 1905), III, pág. $380, \mathrm{~N}^{9} 2111$, y pág. 414, No 2221, respectivamente.

12 Sobre Giovanni Devoti ver The Catbolic Encyclopediat (New York, 1908), IV, pág. 768. Sus obras son: De notissimis in jure legibus libri duo (Roma, 1776), de la que he consultado una $6^{*}$ ed. (Roma, 1826); Juris canonici universi publici et privati libri quinque (Roma, 1803-1815), con nueva ed. (Roma, 1827); e Institutionum canonicarum libri quatuor (Roma, 1785), con 4" ed. (Roma, 1814), de las que he manejado una $3^{\mathrm{n}} \mathrm{ed}$. gandesiana (Gante, 1836), 2 vols., hecha sobre la $4^{\mathrm{a}}$ romana. También he visto unas Institutionum juris canonici tabulae synopticae (Florencia, 1840) basadas en la obra de Juan Devoti. En "Un romance desmentido" Félix Devoti menciona que Carlos Pedemonte "estuvo en Roma en su casa, trató a su familia... le trajo correspondencia y conoció a su hermánó el Obispo. de Agnani" (Alayza, Unanze, pág. 324). El Dr. D. Carlos Pedemonte y Tala. vera (1774-1831), del Oratorio de San Felipe, Rector que fue dell Colegio de San 
$1783^{13}$ En 1803 se graduó Devoti de Bachiller en Medicina en la Real Universidad de San Marcos de Lima, con una tesis sobre la viruela, tesis en la que se titulaba cirujano del Nosocomio del Espíritu Santo; presidió el acto D. Hipólito Unanue. ${ }^{14}$ El lunes, $I^{\circ}$ de agosto de I808, hizo oposiciones a la cátedra de Clínica de San Marcos, que ganó.15 Fue también "profesor de la vacuna" del Colegio de Medicina de San Fernando, inaugurado en I809.18 $\mathrm{Y}$ en I8I9 era también substituto de la cátedra de Prima de Medicina de San Marcos, de la que era titular Unanue. ${ }^{17}$

En cuanto a su actitud política durante los años anteriores a la declaración de la independencia del Perú por el general San Martín el 28 de julio de I82I, decía Devoti en 1824 que había sido "siempre amigo del orden en el antiguo sistema", es decir, en el del gobierno virreinal. Hallo que durante esos años escribió artículos en La Minerva Peruana ya con su firma ya con el transparente anagrama de "Tidevó",18 y lo haría seguramente también en otras publicaciones, anónimamente según era la costumbre de aquellos días. Cuando la invasión de España por Napoleón, deseoso Devoti "de concurrir en cuanto lo permitan mis débiles fuerzas a la defensa de la justa causa", publicó en Lima un Manifiesto contra las instrucciones comunicadas por el Emperador de los franceses a sus emi-

Carlos de Lima (1817-1820), "en abril de 1820 pasó de España a Italia y en mayo del año siguiente se hallaba en Cádiz solicitando pasaporte para regresar a Lima" (Medina, La imprenta en Lima, III, pág. 433). Debió conocet a Giovanni Devoti en los últimos meses de la vida del prelado romano, que falleció el 18 de septiembre de 1820 . En 1824, en los dias en que se publicaba en Trujillo "Un romance desmentido" era Pedemonte arcediano de la catedral del propio Trujillo y había sido en 1822 diputado y presidente del Congreso constituyente peruano. Murió en 1831 en su nativo Pisco, siendo vicario capitular y gobernador eclesiástico del arzobispado de Lima.

13. La imprenta en Lima, III, pág. 380, N? 2111. En el memorial de Devoti que Medina transcribe en ese lugar se dice haber residido. D. Félix "más de treinta años" en los reinos de Santa Fe y el Perú. El memorial no está fechado en esta publicación; por su tenor debe ser de entre 1808 y 1814 .

14 En la Sección de Investigaciones de la Biblioteca Nacional del Perú, Lima, se conserva un folleto impreso con la tesis de Bachillerato de Félix Devoti, Lima, 1803 (Signatura XS8K-D6). Véase su descripción en Medina, La imprenta en Lima, III, pág. 315, No 1932.

is Según se desprende de una invitación al acto que impresa distribuyeron D. Francisco Vázquez de Ucieda y $D$. Pedro Antonio de Molina, descrita por Medina, La imprenta en Lima, III, pág. 390, No 2135 . Desde entonces se titula Devoti en sus obras catedrático de Clínica; ver, p. ej., Medina, La imprenta en Lima, III, No 2202; e Ibid. (Santiago de Chile, 1907), IV, Nos. 2812 y 3168.

16 Ver Obras cientificas y literarias del Doctor D. J. Hipólito Unanue (Barcelona, 1914), II, págs. 448, 451, 479 y 482.

17. La imprenta en Lima, IV, pág. 246, N²3396.

18 Ver, pi ej., La Minerva Peruana, Nos. 60 y 62, de 25 y 29 de noviembre de 1808 , respectivamente. He consultado la colección de este periódico existente en la Biblioteca Nacional, de Lima, que tiene desde el 8 de enero de 1805 al 20 de abril de 1809,6 vols. 
sarios destinados a intentar la subversión de las Américas (Lima, x808), descrito por Medina, ${ }^{19}$ y del que he visto en la Biblioteca Bancroft de la Universidad de California en Berkeley una reimpresión mexicana (México: Casa de Arizpe, I8II), trabajo que le mereció las gracias de Real orden por su celo patriótico. ${ }^{20}$ Se manifestó Devoti liberal, editando con José Joaquín de Larriva El Argos Constitucional de Lima (1813).21 Con el retorno de Fernando VII a la Península de su cautividad en Francia y la supresión de la Constitución de I8I2, Devoti, más o menos a gusto, debió continuar en su actitud de respeto al orden d'el sistema establecido; así se deduce de sus arengas y discursos en actos oficiales de la Universidad de San Marcos, por ejemplo, un elogio de la nación española o un discurso en honor de los militares que defendieron El Callao contra la escuadra insurgente de Chile. ${ }^{2 i 2}$ Durante la época virreinal publicó también Devoti, además de su tesis, otros trabajos propios de su carácter profesional, tales como un Discurso sobre el cementerio general que se ba erigito extramuros (I808), etc. ${ }^{23}$

19 La imprenta en Lima, III, pág. 414, No 2221, y Diccionario de anónimos y sezdónimos bispanoamericanos (Buenos Aires, 1925), II, pág. 47.

20 La signatura del ejemplar mexicano de este Manifiesto existente en la Bancroft Library es F1203-P16-v.13:10. I.a Real orden de gracias en El Verdadero Peruano, Lima, $\mathrm{N}^{*} 2,1^{\circ}$ de octubre de 1812.

21. He manejado la colección de El Argos Constitusional de Lima existente en la Biblioteca Nacional del Perú, que comprende un prospecto y siete números, de 7 de febrero a 21 de marzo de 1813. En su "Prospecto" dicen Devoti y Latriva: "La nueva Constitución política de las Españas, ese esfuerzo sublime del espíritu humano, que no es menos admirable por la época de opresión en que se ha hecho, que por la sabiduría con que están sentadas las bases, distribuidos los poderes, y restituido a cada cual el que debe tener para formar la admirable organización social de una monarquía moderada y permanente, merece ocupar un periódico entero...", etc., etc. El Argos Constitucional es un periódico bien escrito, moderado, que presenta y estudia los preceptos fundamentales de la Constitución de Cádiz, particularmente los que se refieren a la soberanía de la Nación. Según Medina, La imprenta en Lima, IV, págs. 85-86, No 2868, El Verdadero Peruano, periódico limeño que no he visto, publicó de Devoti un "Amor a la Patria, a la Constitución y al Rey", y un "Discurso político", en los Nos. 2, de $1^{\circ}$ de octubite de 1812,8 , de 12 de noviembre de $1812, y$, de 19 del mismo mes y año. También una "Carta de un 'Curioso imparcial' sobre el 'Discurso político", en el $\mathrm{N}^{\circ} 10$, de 26 de noviembre, y la respuesta de Félix Devoti, "Contestación a la carta de un 'Curioso imparcial'" en el $\mathrm{N}^{\circ} 11$, de 3 de diciembre de 1812. En El Verdadero Permano escribió también Hipólito Unanue. Dice Ricardo Palma "Anales de la Inquisición de Lima", Tradiciones peruanas completas, ed. Edith Palma [Madrid, 1952], pág. 1255) que Félix Devoti, denunciado en 1796 por proposiciones heréticas por los inquisidores de Cartagena, figura en un registro de los vigilados por los de Lima.

22 Ver José Toribio Medina, La imprenta en Santiago de Cbile desde sus origenes basta febrero de 1817 (Santiago de Chile, 1891), págs. 146-147 (ref. a Gazeta del Gobiemo de Cbile [realista], tomo I, $N^{\circ} 12$, de 2 de febrero de 1815 , y tomo II, $\mathrm{N}^{2} 13$, de 9 de febrero de 1815); y La imprenta en Lima, IV, pág. 246, No 3396.

23 Existen ejemplares de él en la Biblioteca Nacional del Perú, Lima, signa- 
Una nueva época de gran actividad se inició para D. Félix con la proclamación de la independencia del Perú en I82r. En efecto, "desde que se declaró la Independencia ha sido adicto al sistema, y no a ningún hombre en particular ... Liberal por principios, ama a la libertad por sí misma", escribió en I824. A la época independiente pertenecen sus trabajos en la Sociedad Patrióticaª y en El Sol del Perú, que ya mencionamos, y particularmente, a nuestro propósito, "Las Ruinas de Pachacamac" y su secuela.

Adlicto a San Martín y a Monteagudo en Lima en I821 y 1822 parese ser, sin embargo, que ese último año firmó la petición al Director Torre Tagle que dio por resultado la deposición y el extrañamiento del Perú del Ministro argentino. A las consecuencias de esta actuación de Devoti se refiere un gracioso, aunque procaz, artículo del periódico publicado por los realistas en las fortalezas del Callao, El Desengaño, No. ${ }_{7}^{7}$, de 3 de agosto de 1824,25 titulado "Llegada de Monteagudo a Huanchaco." Este artículo ridiculiza a Sánchez Carrión, a Francisco Xavier Mariátegui y a Félix Devoti, quienes con otros patriotas escaparon a Trujillo, cerca de Bolívar, cuando las tropas realistas volvieron a ocupar a Lima en I824. Estaban llenos de miedo, dice El Desengaño, al enterarse del retorno al Perú del desterrado Monteagudo a reunirse esta vez con el Libertador venezolano. Después de haber sido favorecidos por él cuando era ministro de San Martín, se le habían opuesto en la política de Lima y causado su extrañamiento en I822, aterrorizándose en I824 al verlo favorecido por el nuevo jefe supremo de los independentistas. El artículo es especialmente una sátira contra Devoti, "aturdido viejo italiano", en cuya boca pone un castellano de fantástica mala pronunciación. Pinta a $D$. Félix como un cobarde, que corre de Trujillo a Huanchaco a congraciarse con

turas X718-D65 y X718-D44. Ver su descripción en Medina, La imprenta en Lima, III, pág. $380, \mathrm{~N}^{2} 2111$, donde se menciona también una edición mexicana, de Guadalajara, 1814. Ver también, ibíd., IV, pág. 66, N" 2812. En "Un romance desmentido" menciona Devoti que dio al público sus ideas sobre "Electricidad médica". No he logrado localizar ninguna publicación suya de este título.

24 En la nota 10 supra se indican los trabajos que en ella realizó. El discurso que pronunció en la sesión del 29 de junio de 1822 fue también impreso por separado: Cuadro bistórico politico de la Capital del Perú, desde el 8 de Setiembre de 1820 en que desembarcó en Pisco el Exército Libertador, basta fines

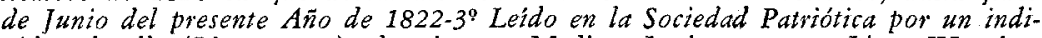
viduo de ella (Lima, 1822), descrito por Medina, La imprenta en Lima, IV, págs. 306-307, N 3630, y Diccionario de anónimos, I, pág. 118. En el Nuevo Día del Perú hay un artículo ¿de Devoti? sobre el mismo tema, resumido, y llevado hasta febrero de 1824 (Alayza, Unanue, págs. 308-313, 316-318, 322-324 y 332-334).

25 Utilizo el texto de El Desengaño (Nos. 1, de 4 de abril de 1824, a 25, de 12 de enero de 1825) reimpreso en la Colección de periódicos peruanos antiguos: El Revisor, ed. Juan Pedro Paz Soldán (Lima, 1921). Ver el artículo de referencia a las páginas 2-3 de la reimpresión del periódico en cuẹtión. 
Monteagudo, a decirle que había borrado con lágrimas la firma que habia - puesto en el manifiesto contra él, le sirve de espolique en su cabalgada a Trujillo, le toma el estribo, etc. Fue este artículo de El Desengaño la ocasión de la autobiográfica defensa de Devoti en su escrito de El Nuevo Dia del Perú del Is de julio de 1824 que he citado.

De algún interés para la historia de la literatura peruana es también el hecho de que Félix Devoti hubiera sido encargado en I822 y I823 de la administración del Teatro Principal de Lima, propiedad de la Hermandad de San Andrés. En enero de 1823 presentó la cuenta de un año de administración en la que, tras relación de ingresos y gastos, aparece un saldo de nueve mil pesos a favor de los asentistas. Parece que fue administrador del Teatro hasta $1826 .^{26}$

En una busca en periódicos peruanos posteriores a 1824 no he vuelto a encontrar la firma de Félix Devoti. En ese año decía él mismo encontrarse ya "en el último período de su vida ... y en una edad avanzada."

\section{IV}

Se nos presenta ahora el problema de identificar quién se encubre con el seudónimo de "Justo Agrícola", firma que aparece al pie del "Artículo comunicado" del No. 21, de 6 de abril de 1822, del Correo Mercantil, Politico y Literario, que comenta "Las Ruinas de Pachacamac" de Devoti.

Por las razones que voy a indicar me inclino a creer que quien se esconde a medias bajo ese seudónimo es Hipólito Unanue. En primer término el tono del escrito es amistoso y elogioso con respecto al autor de "Las Ruinas de Pachacamac" cuando "Justo Agrícola" habla en primera persona (cuando critica a Devoti lo hace por medio de la interposición de un presunto antiguo condiscípulo, su huésped por unos días), y Unanue habia sido, era entonces y fue más tarde amigo de Devoti: ambos eran compañeros de profesión; Unanue presidió el acto de defensa de la tesis de Bachiller en Medicina de Devoti, en r803, 27 Devoti fue profesor en el Colegio de Medicina de San Fernando, fundado a instancias de Unanue; ${ }^{28}$ Devoti fue sustituto de la cátedra de Prima de Medi-

26 M. Nemesio Vargas, Historia del Perí independiente (Lima, 1903), I, págs. 201-202; y Rubén Vargas Ugarte, S. J., Manuscritos peruanos en la Biblioteca Nacional de Lima (Lima, 1950), pág. 213, No 1112.

27 En Theses medicae de variolis, de Devoti, se indica "praeside D. D. Josepho Hippolyto Unanue". Ver n. 14 supra.

28 Ver n, 16 supra. 
cina en I819, cátedra de la que era titular Unanue;29 ambos fueron miembros fundadores de la Sociedad Patriótica de Lima, que Unanue vicepresidía, ${ }^{30}$ y en la que, según antes vimos, tomó parte tan activa Devoti en las sésiones y en la comisión editorial de El Sol del Peru; más tarde, en I824, juntos Unanue y Devoti redactaron y publicaron en Trujillo El Nuevo Día del Peri ${ }^{31}$ En segundo lugar, Unanue había utilizado en el antiguo Mercurio Peruano el seudónimo "Félix Agrícola",32 tan parecido al de "Justo Agrícola." Y en tercer lugar, el "Artículo remitido" al Correo lleva la indicación "Carta escrita de Lunaguaná al editor con fecha 28 de marzo." Lunaguaná o Lunahuaná es una localidad en el valle de Cañete, valle en el cual poseía Unanue las haciendas de San Juan de Arona, Gómez, Pepián y Cerro Blanco, que había heredado de su antiguo discípulo Agustín de Landábaru y Belzunce; 33 tal indicación debía hacer transparente el seudónimo para sus contempotáneos.

No es necesario por cierto identificar aqui a Hipólito Unanue (1755I833), el prócer peruano de tan relevante actuación científica, literaria y política. 34: Si el "Artículo comunicado" no es suyo, no se me ocurre otro literato peruano de aquellos días en el que concurran los elementos indicados en el párrafo anterior y sobre todo que poseyera bienes por Lunahuaná y el valle de Cañete.

El autor de "Las Ruinas de Pachacamac" se presenta a sí mismo en ese rasgo literario sentado en las ruinas del antiguo templo, con la imaginación exaltadla por lo que contempla, imbuido de la dulce melancolía de la soledad, reflexionando sobre el destino de la nación-incorrupta y sencilla- que había construido tales monumentos. Continúa con la descripción de la caída del sol sobre el mar vecino, de las sombras que avan-

29 Ver n. 17 supra. Ver también Unanue, Obras cientificas y literarias, I, pág. xxiii, y II, pág. 450 .

30 Ver Decreto de fundación y Reglamento de funcionamiento de la Sociedad Patriótica y las actas de sus sesiones (Ns. 1 y 2 supra).

31 Alayza, Unanue, págs. 162-163 y 307-400.

32 "Copia de una carta escrita de la villa de Cañete a la Sociedad [de Amigos del País] con fecha 15 de febrero de 1791", firmada "Félix Agrícola", Mercurio Peruano, I, No del 24 de marzo de 1791, págs. 226-228. Debo esta nota a la Srita. Graciela Sánchez-Cerro, Jefa de la. Sección de Investigaciones Bibliográficas de la Biblioteca Nacional, Lima.

33 Alayza, Unanue, pág, 13.

34 Ver, por ejemplo, Ias citadas Obras cientificas y literarias del Doctor D. J. Hipólito Unanue (Barcelona, 1914), 2 vols., xxiv-206 y vii-501 págs., o, entre otros, el libro de Alayza antes indicado. 
zan, de las aves nocturnas que le infunden misterioso horror y-como José María Heredia "sentado en la famosa choluteca pirámide" - pasa de las impresiones de la naturaleza y de la exaltación imaginativa a consideraciones filosófico-históricas, preguntándose por fin por las causas de la desaparición del pueblo que edificó a Pachacamac. ¿Quién lo ha hecho desaparecer? "La tiranía española", le responde el genio tutelar de las tuinas que se le aparece, majestuoso y severo, coronado de vistosas plumas, ceñida la frente del cordón imperial de los Incas. El genio le explica al autor la belleza de la religión antigua, las exquisiteces de su culto, la beneficencia de los emperadores, su paternal y económico gobierno, la laboriosidad y la felicidad de sus pueblos, la ciencia de sus amautas, la clemencia y la humanidad de sus guerreros; todo ello perdido por la perfidia, la crueldad y la malicia de la odiosa raza de los conquistadores; pero ya Pachacamac mismo, ceñida la espada de la justicia, ha decretadlo la venganza. A esta voz ábrese la tierra y mil espectros sangrientos la repiten. Sí, las víctimas de la barbarie española serán vengadas por el héroe que, nacido en las márgenes del Paraná, traspasando los Andes, llega al Perú a romper sus cadenas y a proclamar su libertad. Libertad resuena por todas partes y el antiguo imperio de los Incas va a renacer, más glorioso y brillante todavía. La Nación, bajo leyes imparciales y sabias, merecerá la admiración de las demás del globo.

Al leer "Las Ruinas de Pachacamac" me pareció haber encontrado un ejemplo peruano de la literatura de ruinas, sentimental y filosófica, a la que fueron tan aficionados los escritores europeos de fines del siglo XVIII (recuérdese, por ejemplo, en nuestra tradición literaria, la epístola desde el Paular, de Jovellanos), literatura en la que se ha querido ver un pródromo del romanticismo, y a la que va unida en este texto el indianismo de origen marmonteliano, robertsoniano y raynaliano (recuérdese también en nuestra tradición literaria el de Quintana). Posiblemente en el romano Devoti pueda existir también alguna influencia del pensamiento de los iluministas italianos que se ocuparon de América. ${ }^{35}$

A pesar de insertarse en todas esas modas que ya prevalecían por Europa, el artículo de Devoti produjo en Lima una inmediata reacción crítica desfavorable. El neoclasicismo y el utilitarismo de la mayoría de los intelectuales limeños de esos días eran todavía químicamente puros, por lo menos en la teoría.

35 Ver, p. ej., Aldo Scaglione, "Il pensiero dell'Algarotti. I 'Saggi' sul Cartesio, sul Triumvirato e sugli Incas", Convivium, IV (1956), 404-426, especialmente las págs. 416-426. El ensayo sobre el imperio de los Incas, fechado en 1753. fue publicado en $1764-1765$. 
Verdad es que "Justo Agrícola" en su "Artículo comunicado" del Correo Mercantil comienza elogiando el estilo de "Las Ruinas de Pachacamac", "primera muestra del buen gusto que reina en esa corporación [la Sociedad Patriótica]. Imágenes vivas, exactas, descripciones risueñas, ideas filosóficas, moralidades oportunamente manejadas, cuanto puede producir de más brillante el entusiasmo de la imaginación, todo me pareció reunido en este rasgo bajo de un estilo encantador, enérgico y castizo." Igualmente alaba "la feliz elección del asunto, la importancia política de éste, y el aire de novedlad con que está desempeñado." Pero tras este exordio elogioso introduce "Justo Agrícola" en su artículo la figura de un supuesto huésped, crítico adusto y descontentadizo, pero que "no carece de buenos principios y puede pasar por literato." Este es quien, si bien califica el artículo de Devoti de "lindo rasgo... bien desempeñado, en cuanto al género de su composición", le aplica inmediatamente lo dicho en los versos I5, I6 y ig del Arte Poética de Horacio: "purpureus, late qui splendeat, unus et alter / adsuitur pannus" (aunque olvidando la voz "adsuitur", según luego le reprochará Devoti), y "sed nunc non erat his locus." 36 Es decir, que reduce la obra a la categoria de los "retales de relumbrón." Indica también que no falta en Lima quien diga que el artículo es un plagio de Volney, aunque él personalmente cree que la imitación de Devoti tiene una ventaja sobre la obra que imita y es que se trata de una como miniatura de ella, sin los delirios de la razón extraviada del autor francés. ${ }^{37}$ Protesta entonces "Justo Agrícola" que no es flaco mérito en

36 Se refiere a los versos 14 a 19 del Arte Poética: "Inceptis gravibus plerumque et magna professis / purpureus, late qui splendeat, unus et alter / adsuitur pannus, cum locus et ara Dianae / et properantis aquae per amoenos ambitus agros / aut flumen Rhenum aut pluvius describitur atcus; / sed nunc non erat his locus..." Nuestro neoclásico Tomás de Iriarte había parafraseado hacía poco tiempo ese texto, así: "A veces a un principio altisonante / Que grandes cosas entra prometiendo, / Suele alguno zurcir tal cual remiendo / De púrpura brillante; / Como cuando describe, por ejemplo, / Ya el bosque de Diana, ya su templo; / $\mathrm{O}$ el arroyuelo que la fértil vega / Acelerado y tortüoso riega; / $\mathrm{O}$ bien el caudaloso / Curso del Rin, o el Iris lluvioso./ Pero allí nada de esto cra del caso" (Colección de obras en verso y prosa de D. Tomás de Yriarte. Tomo IV [Madrid, 1787], pág. 3), aclarando en una nota (pág. 69, n. 4): "Aconseja Horacio que se eviten las descripciones pomposas y las digresiones inoportunas. La selva Aricina, consagtada a Diana, solía dar ocasión a los malos poetas para detenerse en prolijas e incoherentes pinturas. Lo mismo sucedía con el Rin...", etc. Es evidente la intención del crítico de Devoti al utilizar ese texto de Horacio.

37 Nótese en el texto del artículo (Anejo $\mathrm{N}^{\circ}$ 2) que en este párrafo se le escapa al autor del "Artículo comunicado" hablar del de "Las Ruinas de Pachacamac" como "nuestro socio". Una presunción más para ver en aquél al hacendado de Lunahuaná, consocio de Devoti en la Sociedad Patriótica, Unanue. Otro detalle: dice igualmente el texto que el crítico no conoce el libro de Les Ruines pero que ha adquirido de esta obra idea bastante en la Biblioteca Columbiana (Sobre esta última publicación ver Medina, La imprenta en Lima, IV, pág. 283, Nos. 3528 y 3529). Pues bien, según Alayza, Unanwe, pág. 34, de las actas de 
la infancia de la regeneración peruana competir con autores de la fama de Volney y así "nuestros adelantamientos en la literatura van a ser muy rápidos." A lo que replica su alter ego: "Puede ser, si esta palabra de tan extenso significado se quiere limitar a esas producciones de moda que embelesan a la imaginación y no satisfacen al entendimiento." Y lanza entonces una diatriba contra las obras que, como el rasgo poético de Devoti, se basan sólo en la inventiva de una vena fecunda, en un estilo que llama rebuscado, en los primores del ingenio, pero que están "vacías de enseñan$z a$ ", obras que le parecen perniciosas precisamente por lo atractivas que son. En lugar de ellas pide obras que enseñen sólidas verdades aunque sea en estilo familiar y humilde, porque "el Criador no ha dotado al hombre de las facultades intelectuales sino para que las ejercite en cosas útiles." Si se le arguyera que el autor de "Las Ruinas de Pachacamac" quiso enseñar al pueblo el odio que merece la tiránica usurpación de los españoles, contestará que el lenguaje de la pieza "no es el más inteligible al pueblo rudo." Parece además que Devoti da por sentado que el gobierno del Perú ha de ser monárquico y "no como quiera, sino dando a los peruanos esperanzas de que han de ver restablecido el antiguo imperio de los Incas", asunto que no desea el crítico discutir.3s Lo que sí quiere pedir es que se publiquen en El Sol del Perú, no obras de ingenio, sino verdades prácticas, asuntos de pública utilidad, al lado de los cuales las "Ruinas" son "lo mismo que el ciprés de que habla el poeta, pintado en el lienzo del náuf rago"; 39 es decir, algo francamente inoportuno. Las ruinas

inventarios de los bienes dejados por Unanue, terminadas en Cañete el 30 de diciembre de 1833, resulta que entre sus libros estaba el Viaje de Egipto, de Volney, pero no Las Ruinas.

38 Siendo la posición política de Unanue en ese momento, siguiendo la de San Martín y Monteagudo, favorable a la instauración de una monarquia europea en el Perú, como se comprueba con las instrucciones secretas que con otros políticos firmó para los enviados diplomáticos a Europa, del Río y Soublette, que iban en busca de un príncipe que aceptara tal corona, la frase del texto que anotamos pudiera hacer creer que no es él el "Justo Agrícola" que firma este trabajo. Obsérvese, sin embargo, que las palabras en cuestión están puestas en boca no del propio "Justo Agricola" sino del supuesto interlocutor suyo; y obsérvese además que es la idea de un (subrayado en el texto) "antiguo imperio de los Incas" lo que le preocupa, como hubiera en efecto podido preocupar a cualquier pudiente criollo de la época que tenía siervos indios. Recuérdese que el propio Bolívar dijo, al comentar la aparición del Inca en el poema de Olmedo en su honor, que bien podían ser los patriotas los vengadores de los antiguos indios pero que no por ello dejaban de ser descendientes de quienes habían aniquilado el imperio inca. (Ver la carta de Bolívar de 12 de julio de 1825 a José Joaquín de Olmedo, p. ej., en las Posias de éste, ed. Clemente Ballén [París, 1896], pág. 264).

39 Horacio, Arte Poética, yersos 19-21: " $\because$. et fortasse cupressum / scis simulare: quid hoc; si fractis enatat exspes / navibus, aere dato qui pingitur?...". Texto que Iriarte parafraseó así: "Sabrás pintar acaso / Un ciprés; y ¿qué sirve? si el que viene / A darte su dinero, te previene / Le pintes un marítimo fracaso / 
del antiguo Pachacamac deberían ser objeto del estudio del filósofo, del geómetra, del arquitecto, del anticuario y no servir de objeto a una pieza de mero entretenimiento: "Escribase lo que se quiera, pero sin olvidar que la obra no será perfecta mientras no se consiga unir en ella la utilidad con el agrado".40 Precepto que sabe tanto a Boileau como a Horacio y ante el cual "Justo Agrícola" confiesa: "Nada pude oponer a estas reflexiones que me parecieron juiciosas."

Esta suerte de crítica, en Lima y en I822, estaba basada en conceptos setecentistas de la literatura: en el concepto de la literatura como algo mucho más amplio que las solas. Bellas Letras; en el concepto de la necesaria utilidad y didactisismo de la literatura; en el concepto de los distintos géneros y los distintos niveles de la literatura, según el cual la de mero deleite o entretenimiento es inconsecuencial - pueril, había dicho Luzán; impropia de hombres graves, según Jovellanos. Conceptos todos de un perfecto iluminismo y de su paralelo un perfecto neoclasicismo que constantemente ponen en los puntos de la pluma del crítico las palabras del Arte Poética de Horacio.

Quizás antes de examinar la respuesta que dio Devoti a las críticas que contiene el "Artículo comunicado" del Correo convenga aclarar la cuestión de su imitación de Volney. Que Devoti para su artículo se inspiró en Les Rutines ou Méditation sur les Révolutions des Empires (I791) se le ocurre a uno en seguida de leer aquella producción y se comprueba con dar un vistazo comparativo a los dos textos. ${ }^{41}$ En el capítulo primero de Lés Ruines (pág: 4) se sienta Volney en una columna rota, entre las ruinas de Palmira, a reflexionar ensoñando, y Devoti comienza sus "Ruinas" sentado en las ruinas del templo de Pachacamac, invadido de una dulce melancolía. Volney (pág. 3) entra en Palmira en lo que fue el templo dedicado al Sol, y Devoti mira en Pachacamac los restos del antiguo templo del Sol. "Le soleil venoit de se coucher; un

En que él sobre una tabla destrozada, / Sin esperanzas de la vida, nada" (págs. 3-4).

40 "Omne tulit punctum, qui miscuit utile dulci / lectorem delectando pariterque monendo", Horacio, Arte Poética, versos 343-344. En la paráfrasis de Iriarte: "Mas todos con su voto contribuyen / Al que enseñar y deleitar procura, / $Y$ une la utilidad con la dulzura" (págs. 47-48). Y Boileau: "Qu'en savantes leçons votre Muse fertile / Partout joigne au plaisir le solide et l'utile" (Oeuvres poétiques, ed. Ferdinand Brunetière, $3^{\mathrm{a}}$ ed. [París, 1899], pág. 224).

41 Cito por la $2^{a}$ ed. de Les Ruines (París, 1792), xvi-350 págs. y 3 grabados. Sobre Constantin François Chasseboeuf-Boisgirais-Vonley (1757-1820), ver, p. ej., la "Notice sur la vie et les écrits de C. F. Volney", por Adolphe Bossange, que encabeza el tomo I de las Oeuvyes de C. F. Volney, $2^{\text {a }}$ ed. completa (París, 1826), págs. i-xlix. De Les Ruines existe una traducción española publicada en Londres en 1820, que no he visto (Ver E. Allison Peers, Historia del movimiento romántico español, trad.- José $M^{7}$ Gimeno [Madrid, 1954], II, pág. 463, nota 185). 
bandeau rougeâtre marquoit encore sa trace à l'horizon lontain...", describe Volney (pág. 3), y Devoti: "El Sol ya en el ocaso no presentaba sino la mitad de su disco rojo desnudo de sus rayos". Volney (pág. 4): "un vaste silence régnoit sur le désert; seulement, à de longs intervales, l'on entendoit les lugubres cris de quelques oiseaux de nuit et de quelques chacals... L'ombre croissoit, et déjà dans le crépuscule mes regards ne distinguoient plus que les fantômes blanchâtres des colonnes et des murs"; y Devoti, alterando ligeramente el orden y entenebreciendo el ambiente: "Las sombras avanzándose desde las montañas anunciaban la terrible pausa de la naturaleza, y las aves nocturnas revoloteando por entre las derrocadas paredes infundían un misterioso horror, que se aumentaba con la calma, interrumpida sólo por los monótonos chillidos del grillo. Arrebatado con la vista de tantos objetos que iban poco a poco perdiendo la regularidad de sus formas...", etc. Esta contemplación que en Volney produce "un recueillement réligieux", "hautes pensées" (pág. 4) y una "mélancolie profonde" (pág. Ir), produce en Devoti primero "una dulce melancolía, que es el verdadero patrimonio de la razón", y luego una "imaginación exaltada" y un "entusiasmo" poético que lo conducen, como a Volney, a reflexiones históricas, morales y políticas sobre el destino de las civilizaciones y los pueblos antiguos que contemplan. Es más, en su capítulo tercero, titulado "Le Fantôme", Volney ve "un fantôme blanchâtre enveloppé d'une draperie immense, tel que l'on peint les spectres sortant des tombeaux" (pág. 12), que en los sucesivos capítulos va a ilustrarle sobre el pasado y el futuro; y Devoti, adaptando la escena al ambiente peruano, describe el genio inca guardián de las ruinas de Pachacamac que se le aparece a él para ejecutar un cometido parecido al que cumple el fantasma en la obra de Volney. No hay duda de que Les Ruines proveyeton a Devoti de título, de escenografía y hasta de léxico para su "Ruinas". 42

Pero las críticas dirigidas en el artículo de "Justo Agrícola" a Devoti no iba éste a dejarlas sin contestación y así lo hizo, en efecto, en su "Respuesta al Censor de Las Ruinas de Pachacamac", en el № 4 de El Sol del Perú que reprodujo El Correo Mercantil, en su $\mathrm{N}^{\circ} 23$, poniéndole réplica en notas de pie de página. Sospecho que las notas de réplica no sean de "Justo Agrícola" porque en ellas se habla de éste en tercera persona y más

42 La edición de 1792 de Les Ruines va encabezada por un grabado que, con ligerísimas alteraciones, pudiera ilustrar "Las Ruinas de Pachacamac". Representa un hombre enturbanado, sentado sobre un resto de columna, bajo un árbol (que supongo la estilización de una palmera), contemplando las ruinas de una ciudad antigua, situada en una llanura desértica que se extiende hasta el horizonte. 
todavía porque son de un tono a veces virulento, como no lo es el texto de aquél ni los de Unanue en general, si este prócer fue, como creo, el primer crítico. Por necesidades lógicas y de economía de espacio vamos a ocuparnos de la respuesta de Devoti y de las notas del Correo conjuntamente.

Después de algunas fintas preliminares, Devoti afirma que el censor de sus "Ruinas" clebe de tener "ideas muy circunscriptas", es decir, dogmáticas y limitadas; a lo que una nota replica que no lo serían tanto que no bastasen a conocer lo bueno que hay en las "Ruinas" y a elogiarlo como lo elogió. Aquella frase de Devoti hace esperar que su subsiguiente defensa va a basarse en un concepto más libre de la literatura que el preceptivo y utilitario de su crítico; pero todo el resto de ella, como las notas del Correo que la comentan, son una serie de juegos interpretativos de los consejos del Arte Poética de Horacio y su aplicación al caso controvertido. Por ejemplo, a la acusación de que plagia o imita a Volney, responde Devoti que había sido educado en mejores modelos que ese autor moderno, pero que aunque lo hubiera tomado por modelo nada habría en ello de vitando porque también Virgilio imitó a Homero y Horacio a Píndaro, y que en la imitación entran no sólo los planes sino también las figuras, los giros y aún las palabras. ${ }^{43}$ ( $A$ lo que irónicamente responde $\mathrm{El}$ Correo: "pero no tan servilmente como en Las Ruinas de Pachacamac"). Inmediatamente toma Devoti la of ensiva contra su censor señalando que al decir éste los versos 15 y 16 del Arte Poética omitió la voz "assuitur" ("adsuitur"), quitándole así al verso su armonía y el sentido a la imagen, con lo que a su vez da ocasión a una nota del Correo que le apunta un error en la comprensión del mismo texto horaciano. Otro choque se produce entre Devoti y el autor de las notas de réplica porque aquél dice - al defender su uso de ruinas, genios y fantasmasque en lo triste y asombroso están las fuentes del verdadero sublime. El anotador se lo refuta, basándose en la autoridad de Longino. ${ }^{44}$

Pasando aquí por alto los párrafos siguientes de la "Respuesta" - y una burlona nota del Correo- sobre el aspecto político de "Las Ruinas de Pachacamac", "45 se encuentra una nueva diferencia de opinión entre

43 Versos 268-269 del Arte Poética: "...Vox exemplaria Graeca, nocturna versate manu, versate diurna", que Iriarte traduce: "Revolved... las obras de los griegos noche y día" (pág. 37). No se atrevió Devoti a referirse a los versos 131-135 que recomiendan no seguir a la letra la materia y los giros de la obra que se imita, no ser como el intérprete que traduce palabra por palabra. A lo mejor estos versos estaban en la mente del anotador que se burlaba de la servilidad de Devoti en su imitación de Volney.

44. La referencia debe ser al capítulo 8 de De lo sublime.

45 aun en este punto trae Devoti a colación a Cicerón, Plutarco y Platón. 
Devoti y su anotador con respecto a la expresada en el artículo de "Justo Agrícola" d'e que a las obras de mero entretenimiento debe preferirse la exposición de verdades y de sólidas doctrinas aunque sea en estilo familiar y humilde. Ambas partes fundamentan su respectiva posición con nuevas citas de Horacio. $Y$ ello con gran gusto del anotador que se apunta un tanto al poder echarle en cara a Devoti que si "Justo Agrícola" olvidó una palabra en una cita del latino, él, Devoti, lo cita mal, alterando la medida ("humi repit" dice D. Félix en vez del "serpit humi" del verso veintiocho), ${ }^{46}$ con el "garrafal error" que hubiera sido en Horacio "principiar el verso con un jambo cual es 'humi"." Devoti sostiene por su parte que "querer en el gusto del siglo... que se escriba en estilo bajo y humilde" es impensable, y que ningún trabajo literario escrito con elegancia dejará de reportar alguna utilidad, pues si no contiene "en su totalidad los partos del entendimiento, llevará consigo las graciosas pinturas de la imaginación". A lo que el anotador replica con el viejo truco forense de retocar el argumento del contrincante hasta hacerlo absurdo: ¿Cómo puede ser de utilidad un trabajo escrito con elegancia pero en el que "no tenga parte el entendimiento"? La última frase de la "Respuesta" de Devoti es realmente la flecha del Parto disparada por aquél a "Justo Agrícola" al recordarle que, siguiendo el consejo de Horacio ("qui miscuit utile dulci, lectorem delectando, pariterque monendo"), hasta el propio Mercurio Peruano, de Unanue, mezcló los partos del entendimiento y las graciosas pinturas de la imaginación.

\section{VI}

Devoti defendió "Las Ruinas de Pachacamac" blandiendo su inter. pretación de preceptos y textos clásicos, tal como con textos y preceptos clásicos fueron criticadas por su antagonista (o antagonistas). Todos se creían profundamente clásicos (neoclásicos, diríamos hoy). Todos estaban empapados de cultura antigua, de los buenos modelos antiguos, de preceptistas antiguos, que eran para ellos los árbitros y los legisladoces del gusto.

Ello no obstante, "Las Ruinas de Pachacamac" son una temprana muestra peruana de lo que ya hasta el propio Devoti, teóricamente tan.

46 "Serpit humi tutus nimium timidusque procellae" ("Este que acobardadol Teme la tempestad, y no alza el vuelo, / Siempre humilde se arrastra por el suelo": [Iriarte, p. 57]). La réplica del anotador de Devoti se basa en el verso 95: "et. tragicus plerumque dolet sermone pedestri" que. D. Tomás parafraseó: "Y en otras [ocasiones] se lamenta la Tragedia/Con humilde y popular estilo" (pág. "13). 
neoclásico, llamó "el gusto del siglo", gusto que más que al racionalismo, al intelectualismo, al academicismo y al utilitarismo que prescribía, por ejemplo, el Decreto de fundación de la Sociedad Patriótica de Lima, tendía a "las graciosas pinturas de la imaginación" y aun "de la imaginación exaltada", y a la expresión del sentimiento ("la dulce melancolía", "el entusiasmo"). Unos años más y del gusto del siglo se pasará al mal del siglo.

Es curioso que el autor de "Las Ruinas de Pachacamac" fuera, en r822, en Lima, en El Sol del Perú, un italiano, Félix Devoti, como otro italiano, Luis Monteggia, fue en El Europeo, en Barcelona, en $1823 \mathrm{y}$ r824, uno de los primeros propugnadores en España de lo que ya expresamente llamaba "romanticismo", que para él se distinguía (entre otras características) por un estilo de colorido melancólico y sentimental, por lo patético de los cuadros y por la elección de argumentos interesantes, sin más ley que ésta, la de lo interesante. ${ }^{47}$ Con estos términos de Monteggia se podría sin gran dificultad describir lo que hizo Devoti en "Las Ruinas de Pachacamac", que él defendía en cambio con su interpretación de los preceptistas clásicos.

El mismo Correo Mercantil, Político y Literario que publicó las críticas clasicistas contra "Las Ruinas de Pachacamac" no deja de mostrarse influido por ese gusto del siglo, ya que ocho o nueve semanas más tarde, el 23 de junio de r822, imprimía bajo el título de "La Grecia", una traducción bastante parafraseada de unos cuantos versos de The Giaour, de Byron, aunque sin indicar el título del poema original, el nombre de su autor ni el del traductor. ${ }^{48}$ Dieciséis meses después de publicar este trozo publicó también otro, traducido de The Age of Bronze, igualmente de Byron, pero indicando entonces, con elogio, el nombre del poeta inglés. ${ }^{49}$

47. Ver Peers, Historia del movimiento romántico, I, págs. 203-204 y 206; y textos de Monteggia en el índice de El Europeo (Barcelona, 1823-1824) (Madrid, 1953), por Luis Guarner.

48 Correo Mercantil, Político y Literario, Lima, No 33 , de 23 de junio de 1822, pág. 4: "iÂlzate! ¿ves desde estos altos montes, / que tus ojos dominan, estos mates? / ¡Es Salamina! ¿Ves aquestos campos? / iSon los de Maratón! ¿Estas montañas? / ¡Las Termópilas son! / Estos lugares / De mil y mil recuerdos siempre abundan, / Estas rocas su gloria...", etc., etc. Ver el texto inglés en The Poetical Works of Lord Byron, Oxford ed. (Londres, 1921), pág. 246: "Say, is not this Thermopylae? /. These waters blue that round you lave / ... / Pronounce what sea, what shore is this? / The gulf, the rock of Salamis! / These scenes, their story not unknow, / Arise, and make again your own;"' etc.

49 Correo Mercantil, Politico y Literario, $N^{0} 11$ del tomo II, de 18 de octubre de 1823, pág. 4. Es la traducción, algo parafraseada, de los treinta y tres últimos versos de la parte $\mathrm{V}$ de "The Age of Bronze"; ver el texto inglés en The Poetical Works cit., págs. 167-168. Esta traducción fue mencionada y reproducida por Estuardo Núñez, Autores ingleses y norteamericanos en el Perí (Lima, 1956), págs. $81-82$ y $280-282$. 
$Y$ un par de años después de la controversia sobre "Las Ruinas de Pachacamac" aquí reseñada, el propio Unanue publicó en los números de El Nuevo Día del Perí, de Trujillo, de Iํ, 8 y 29 de julio de I824, un texto titulado "Las Ruinas del Valle de Santa", ${ }^{50}$ que pertenece al mismo género que "Las Ruinas de Pachacamac". Y su nieto, "Juan de Arona" (Pedro Paz Soldán y Unanue), amante de los clásicos y traductor de un libro de las Geórgicas por una parte, publicaba también por otra parte una colección de poesías titulada precisamente Ruinas. ${ }^{\sigma 1}$

Setecentista por educación y por teorías, no se dio cuenta quizás Félix Devoti de las brechas que con "Las Ruinas de Pachacamac". había abierto en los fuertes muros del neoclasicismo peruano.

\title{
Luis MONGuió.
}

\section{University of Californid, Berkeley.}

\author{
ANEJO N: I \\ De El Sol del Peri, Lima, No I, I4 de marzo de 1822, págs. 2-4.
}

\section{LAS RUINAS DE PACHACAMAC}

"Exoriare aliquis nostris ex ossibus ultor, Qui face Dardanios, ferroque sequare colonos. Virg. lib. IV.AEneid.

Sentado sobre las ruinas del antiguo templo de PACHACAMAC, rodeado por todas partes de estériles y desiertas arenas, mi imaginación se exaltaba a la vista de aquellos preciosos escombros que aún recuerdan sur pasada grandeza. La perspectiva del hermoso valle que se divisaba en distancia, la soledad y el silencio, me infundian aquella dulce melancolía, que es el verdadero patrimonio de la razón, y que el hombre desprecia en el bullicio de las ciudades. Informes masas, paredes elevadas que se presentan en extraños y distintos aspectos, no hacian alarde de aquellos

50 Ver este texto en la reproducción del Nuevo Día del Perú en Alayza, Unanue, págs. $313-314,320-322$ y 340-344. Apareció en las fechas citadas en el texto en los Nos. 1,2 y 5 del periódico. 388 págs.

51 Ruinas, Colección de ensayos poéticos por Juan de Arona (París, 1863), 
soberbios ornatos que ennoblecen los carcomidos monumentos de la antigua Grecia y de Roma; pero en cambio la solidez del edificio que se percibe, su vasta extensión, y la regularidad de su forma, manifiestan aún el inmenso poder de la Nación que pudo elevarlo, la inteligencia, sabiduría y genio de sus artífices. Esta Nación, me decía a mí mismo, segregada por inmensos mares de las demás partes del globo, ignorando el arte de pintar la palabra, y sin más auxilio que el de sus QUIPUS para adelantar sus ideas con los trabajos de sus mayores, no conocía las superfluidades de la vida; pero estos monumentos atestiguan su poder, su civilización y su industria. Cuanto más feliz es un pueblo que ignorando la corrupción y los caprichos del lujo, llena con sencillez los grandes fines para los que se han reunido los hombres en sociedad, que no aquel, que vagando por entre los delirios de lo superfluo, se labra a sí mismo sus cadenas, hasta que se ve al fin precisado a volver a la sencillez primera de la naturaleza para llegar a cierto grado de perfección, que tanto más huye de él, cuanto más se desvía de este principio. - Nada hay grande ni en lo moral ni en lo físico, si el arte no se encubre bajo el manto de la misma naturaleza. Los magníficos restos del antiguo templo del Sol que veía a mis espaldas, los vestigios de un acueducto que coronaba la altura del árido cerro destinado a fertilizar estos campos estériles en el día, y la multitud de HUACAS de que estaba sembrado el valle que tenía a mis pies daban pábulo a la imaginación exaltada, y me confirmaban en mis ideas.

El Sol ya en el ocaso no presentaba sino la mitad de su rojo disco desnudo de sus rayos. La Mar tranquila en que iba a sumergirse parecía toda fuego, y las nubes amontonadas en el horizonte variando a cada instante de color y de forma, parecíanse a los fementidos amigos de la corte, que mudan siempre de aspecto, a medida que se cambia el ídolo a quien sirven, hasta tanto que en su caída lo abandonan del todo. Las sombras avanzándose desde las montañas anunciaban la terrible pausa de la naturaleza, y las aves nocturnas revoloteando por entre las derrocadas paredes infundían un misterioso horror, que se aumentaba con la calma, interrumpida sólo por los monótonos chillidos del grillo. Arrebatado con la vista de tantos objetos que iban poco a poco perdiendo la regularidad de sus formas, exclamé en medio de mi entusiasmo. ¿Y adónde está esta Nación tan numerosa y tan grande, que en tiempos más felices elevaba estos monumentos, y pobló estos áridos campos? Se ha disipado como el humo, su poder y su gloria, ¿Quién la ha hecho desaparecer casi toda de sobre el haz de la tierra?... La tiranía -responde una voz terrible que embarga mis sentidos; y a la luz de una pálida llama que de repente 
ilumina aquel árido sitio, veo recostado en lo más alto de sus ruinas el genio que aún velaba en su guarda. Su aire majestuoso y severo anunciaba la elevación de su origen. Vistosas plumas coronaban el trasquilado cabello ceñido del rojo cordón, que hacía caer en ambas sienes la sagrada borla, divisa de los Incas. Colgaban de sus horadadas orejas hasta la espalda dos grandes y brillantes argollas; y ceñido el cuerpo con una ligera túnica hasta su membruda rodilla, dejaba flotar en el suelo la Imperial YACOLLA. - Sí, me dijo: sí la tiranía española hizo desaparecer de la tierra una nación tan grande y poderosa, y con ella arrasó aun la misma esperanza de las generaciones futuras. Tiembla: por doquiera que pisas, pisas las sangre y los insepultos huesos de mil víctimas infelices de la tiranía. Las piedras mismas aún llevan la marca de su furia, pero a pesar de ella y del tiempo, estos magníficos restos pregonarán siempre la ferocidad española, y harán justicia a la civilización de estos pueblos. Compara, oh tú cualquiera que seas; compara, y juzga cual de los dos merece el odioso renombre de bárbaro y salvaje.

Mira: este que ves, este es el templo del gran PACHACAMAC, del supremo hacedor del universo, del que todo lo sostiene y gobierna. Bastaba un solo templo al que era también solo en el universo; ni podía figurarse bajo el miserable aspecto de vanos simulacros a un ser incomprensible, eterno $e$ inmenso. Grande era el respeto que infundía la sombra misma de estos muros, grande el religioso pavor con que pronunciaba su nombre un pueblo inocente y sencillo. Hasta aquí, y no más, era permitido penetrar a los hombres; allá velaban sus sacerdotes; aquel era el sitio destinado a los sacrificios.

Mira: aquel que aún se divisa por entre la obscuridad de las sombras a la falda de ese árido cerro; aquel era el templo del Sol. El Perú agradecido a sus beneficios le elevó altares en todas partes, y los Incas le tomaron por modelo de su gobierno. Todo era exquisito en su culto, todo respiraba la grandeza del numen y la inocencia de una nación religiosa y magnífica. Aún se ven los vestigios del sitio en que vivían consagradas en su servicio las vírgenes más ilustres, tan puras como el rocío de la mañana, intactas como la flor del desierto a quien el céfiro no ha robado aun la fragancia de sus perfumes. Los Incas adoraban como a su padre a este astro vivificador y brillante, y como él desde la elevación de su trono esparcían la luz en todas partes; como él, eran benéficos; como él, alentaban en todos el movimiento y la vida. Un gobierno paternal y económico hacía felices y laboriosos los pueblos. La ociosidad era desconocida o castigada severamente; todo era común; juntos trabajaban en las 
tareas de los campos; juntos disfrutaban de sus productos, sin que jamás se olvidase al desvalido y a la viuda. Los $A M A U T A S$ adoctrinados en las ciencias más útiles dirigían sus trabajos y presidían las labores. Las gueras mismas eran precedidas por la clemencia; la humanidad las seguía; y el soldado, que hallaba en sus marchas abundantes depósitos de armas y víveres en todas partes, no era jamás gravoso a los pueblos, ni al labrador industrioso.

Felices mil veces estos países si la mar no hubise vomitado en sus costas un ejército de bandidos, que guiados por el genio del mal, y armados del rayo, sorprendieron su credulidad inocente. Nos anunciaron el grande espíritu hijo del hombre, símbolo de amor, de fraternidad y de paz; y ellos no respiraban sino perfidia, crueldad y codicia. ¡Cielos, por: qué entonces sufrísteis que este nombre terrible, éste que os crió de la nada, éste que os sostiene y gobierna, sirviese de pretexto y de velo a los crímenes más horrendos! No; no era el Sol el árbitro del universo cuando alumbró con sus rayos esas escenas de horror, y no vengó la destrucción de sus templos y la sangre inocente de sus hijos.-Pero ya el grande, el tremendo $P A C H A C A M A C$ se ha ceñido la espada de la justicia. Desaparecerá esa raza odiosa del suelo que ha sido el teatro de sus delitos. EI cielo se ha cansado de sufrir por más tiempo el triunfo de la tiranía; el cielo mismo ha decretado ya la venganza.

Venganza repitió entonces un eco paroroso desde las concavidades de los cerros; mil bóvedas parecían abrirse, y asomándose en ellas mil sangrientos espectros repetían venganza por todas partes. La tierra se estremeció; desaparece el genio, y la obscuridad que sucede a la fúnebre luz que alumbraba aquellas ruinas embargó mis sentidos, y me dejó sumergido en la admiración y el espanto.

Sí, víctimas desgraciadas de la barbarie española; sí, seréis vengadas. Un héroe que ha producido este suelo en las márgenes del Paraná escuchó vuestros gritos. Desde la nevada cumbre de los Andes extendió sobre el Perú sus miradas, y lleno de aquel noble entusiasmo, que inflama una alma sensible cuando es excitada por la humanidad y la virtud, desde allí juró romper sus cadenas. Desde allí vuela al socorro de los oprimidos; cría fuerzas de la nada, los obstáculos redoblan su energía, surca atrevido los mares y no quiere más recompensa sino la gloria.-Fija el primero en estas costas el sagrado Pendón de la libertad; libertad resuena en todas partes, y los tiranos huyen cobardemente buscando en su desesperación un mal seguro abrigo en la fragosidad de los montes.-Gime bajo sus pies el suelo que los sostiene, y bien pronto el nombre español se conservará para 
servir tan solo de espanto a la niñez, y su memoria nos hará en todo tiempo irreconciliables con el despotismo y la tiranía. Vosotras entretanto, Ninfas del Perú, descendientes de sus primitivos habitantes, dejad las lúgubres vestiduras, olvidad vuestras lastimeras canciones, entonad al vencedor cánticos de alegria. El antiguo Imperio de los Incas va a renacer de nuevo más glorioso y brillante. Nosotros ya reunidos, sin las odiosas distinciones del antiguo egoísmo, no formaremos sino una sola Nación. Revivirá el antiguo esplendor; y bajo el suave dominio de leyes imparciales y sabias, mereceremos en nuestra infancia misma la admiración, y el respeto de las demás naciones del globo.

F. D.

\section{ANEJO N ${ }^{\circ} 2$}

Del Correo Mercantil, Politico y Literario, Lima, No 2I, 6 de abril de 1822 , págs. 2-3.

\section{Artículo Comunicado}

Carta escrita de Lunaguaná al editor con fecha 28 de marzo.

La ilustración no progresa donde no tiene lugar la crítica.

Señor editor.-En una chacarita que poseo en este valle paso la vida tranquilamente, libre de negocios y de las disipaciones de esa capital. Ocupo mi tiempo en los afanes de la labranza, y en las atenciones de padre de familia, y en algunos ratos de conversación con mis vecinos; más a todo prefiero algunas buenas lecturas con que cuido de fomentar cuanto me es posible, en provecho mío y de mis hijos, las tales cuales nociones de las ciencias, que junto con los principios de la religión y los sentimientos de sólida piedad, logré adquirir en la juventud por los esmeros de una feliz educación. Así es que no se publica en Lima y demás estados independientes de América escrito alguno, sin que le solicite yo con ansia; bien persuadido de que en esta época de nuestra regeneración, la libertad de la imprenta ha de ocuparse en difundir las luces de que más necesitamos, instruyéndonos en los derechos y deberes del ciudadano libre, especial- 
mente a los que por acá vivimos sin recurso a las fuentes de la ilustración política. Con particular dedicación me entrego a los papeles de esa capital, por saber el estado de nuestro gobierno, y sus acertadas providencias, los progresos actuales de la prosperidad común y los bienes que para en adelante debemos esperar; porque sé que no existo para mí solo, y que a nadie es permitido ignorar lo que a todos interesa, en virtud de las relaciones recíprocas entre la sociedad y el ciudadano.

Por lo dicho puede V. colegir, señor editor, la complacencia con que habré leído, entre otros papeles que recibi de mi corresponsal en estos días, los dos primeros números del Sol del Perú, que comienza a publicar la nueva sociedad patriótica, y con mayor satisfacción las Ruinas de Pachacamac, primera muestra del buen gusto que reina en esa corporación de sabios. Imágenes vivas, exactas, descripciones risueñas, ideas filosóficas; moralidades oportunamente manejadas, cuanto puede producir de más brillante el entusiasmo de la imaginación, todo me pareció reunido en este rasgo bajo de un estilo encantador, enérgico y castizo; todo arrebató a mi alma y la puso como en éxtasis. Y concibiéndome al lado del autor sentado sobre aquel soberbio monumento que nos pinta con tan vivos colores, me entretenía en cotejar con éste la maestría del pincel, mas sin saber qué merecía mi atención, o la magnificencia del antiguo edificio que aún se trasluce entre sus mismos escombros, la firmeza de esos restos que se han burlado así de la barbarie española como de la fuerza destructora de los siglos, y el poder que allí se nos recuerda del arruinado imperio del Perú, o más bien la propiedad con que el escritor retrata estos objetos, la feliz elección del asunto, la importancia pública de éste, y el aire de novedad con que está desempeñado.

Con el periódico en la mano, y profundamente absorto en estas y otras considetaciones, vino a interrumpírmelas un antiguo condiscípulo mío, acabado de llegar de la capital y a quien tenía de huésped en mi casa. Es preciso advertir que este es un hombre adusto, que nunca toma el caldero sino por donde quema; crítico descontentadizo que se complace de hallar defectos en las mejores obras, y a quien las más bien escritas le desagradan, si no las encuentra análogas a sus ideas o a sus deseos; porque tiene concebido como otros muchos de que abunda nuestro suelo, que nada más necesita para granjear crédito de sabio. Por lo demás, no carece de buenos principios, y puede pasar por literato.

Grande fue mi sorpresa al oír a este hombre que enterado del objeto de mi admiración, echando sobre el periódico una mirada desdeñosa parecida a desprecio, me decía: ¿Las Ruinas de Pachacamac? ¡Eh! - las 
he visto...Purpureus late qui splendeat unus et alter punnus... Sed nunc non erat bis locus. No dejó de indignarme tan inesperada aplicación y más la socarronería con que la profirió; y así le repliqué con viveza ¿Cómo así, señor mío? Qué es lo que $\mathrm{V}$. dice. ¿Tal censura merece una producción como esta?-Excelente producción, me respondió. Si, lindo rasgo, no lo niego. Bien desempeñado, en cuanto al género de su composición. El autor (le conozco por las iniciales de su nombre) aun por esta vez quiso ostentar su genio poético, que es la nayor gala de su lucimiento; tiene la obra cuanto es necesario para colocarla entre los retales de relumbrón de que habla Horacio; aunque no falta quienes pretendan rebajarle el mérito con esparcir que es un plagio de Volney. No diré yo otro tanto, porque no he leido las Ruinas de Palmira para poder hacer el cotejo, y sentenciar por mi propio juicio. Mas en la Biblioteca Columbiana the adquirido de esta obra idea bastante para conocer que las Ruinas de Pachacamac se han vaciado en tal turquesa. Sólo hallo una diferencia que no debo callar, porque cede en honor de nuestro socio. Volney, según dicen, reúne los coloridos más encantadores de la elocuencia, para componer el barniz con que hermosea los delirios de la razón más extraviada, mientras en las Ruinas de Pachacamac se ve imitado perfectamente cuanto oigo celebrar de bueno en aquella obra, y con el mérito de haber reducido como a una miniatura el plan de ella con todos sus primores, para asunto muy diverso; y tengo entendido que en la imitación se emplean, con intento loable, el mismo estilo, las mismas pinturas, el mismo entusiasmo con que el autor francés deslumbra y seduce a los incautos. Pero...

Pero ¿qué? le interrumpí. ¿ $\mathrm{Y}$ éste no es sobrado mérito?-me párece, amigo mío, que lo más a que podíamos aspirar en el día, es a tomar por modelo aquellos autores que corren con mayor aceptación y aplauso. En la infancia de nuestra ilustración ya es dar pasos de gigante, si conseguimos imitarlos con el acierto que en este primer número del Sol,iRivalizar con semejantes escritores! ¡Ahí que es nada! Nuestros adelantamientos en la literatura van a ser muy rápidos.

¿En la literatura? - exclamó este hombre cáustico, pintándose la extrañeza en su semblante. ¡En la literatura!... Puede ser, si esta palabra de tan extenso significado se quiere limitar a estas producciones de moda que embelesan a la imaginación y no satisfacen al entendimiento. A esto y no a otra cosa se reducirían los progresos de la ilustración peruana siempre que nos contentásemos con seguir la ruta indicada por el rasgo poético que tenemos a la vista. Pero igracias a los bien concertados 
reglamentos de la sociedad patriótica! Êsta no se ha propuesto divertir haciendo ostentación de composiciones de moda, cuyo mérito consista en la inventiva de una vena fecunda, y en las bellezas de un estilo rebuscado y filosófico, y en cláusulas pintorescas, y en los demás ornatos de una elocuencia brillante con que lucen los primores del ingenio dejándonos vacíos de enseñanza.

Yo le confesé que no debían preferirse las obras superficiales, por estar hermosamente escritas, aunque sean hoy las de moda; pero que jamás convendría en poner las Ruinas entre las de este género. A lo cual me contestó: esas son las que generalmente agradan, porque se prefiere el entretenimiento a la sólida instrucción; porque proveen a poca costa de clausulitas que dan golpe y de sentencias rumbosas que sirven lindamente para pasarla de eruditos, y de buen gusto; porque pulen el ingenio sin el trabajo de incubar seriamente sobre las materias que más importa saber. Déme $V$. obras que enseñen verdades y sólidas doctrinas, aunque sea en estilo familiar y humilde y a estas me atengo. Las demás cuyo asunto nada influye en el bien de la sociedad, ni me ilustran para rectificar el corazón y formar las costumbres, las miro como obras sin sustancia, por no decir como perniciosas, por cuanto el Criador no ha dotado al hombre de las facultades intelectuales sino para que las ejercite en cosas útiles. Son el lujo de la literatura con abuso del ingenio, a la manera de aquellas pomposas superfluidades de puro lucimiento que se aumentan a las comodidades de la vida sin más objeto que la vanidad o el placer. ¿Y podrá $V$. probarme que las Ruinas tienen asunto de alguna utilidad? Me dirá $V$. que poniendo a la vista un testimonio sensible de los estragos de los españoles, influye en gran manera para radicar en el pueblo el odio de su tiránica usurpación. Pudiera ser. Sin embargo, además de que hay verdades cuya impresión se debilita a fuerza de inculcarlas ¿creeremos de buena fe que ésta fue la intención de nuestro autor? su lenguaje no es el más inteligible al pueblo rudo ¿o escribió para los entendidos que no necesitan de ese recuerdo? Desengañémonos, amigo mío, tan bella producción no se recomienda con este objeto, aunque en si de tanta importancia. No entraré en reflexiones, si el asunto está bien desempeñado, en cuanto a este fin que se debió proponer. Examinen otros si acertó en suponer como ya de hecho, que nuestro gobierno ha de ser monárquico, y nó como quiera, sino dando a los peruanos esperanzas de que han de ver restablecido el antiguo imperio de los Incas, diciéndoles que éste va a renacer de nuevo más glorioso y brillante. No soy político, y debo prescindir dé esta materia, como igualmente de una 
que otra idea que no me agrada mucho en la obra. Pero insisto siempre en lo que insinué al principio. Obra bien escrita en cuanto a su forma, pero que no viene al caso. ¿Y por qué? - porque no contiene doctrina que interese prácticamente a la pública ilustración. Tales son los escritos que precisamos; ni es otro, si no me engaño, el objeto de la sociedad.

El instituto de ella comprende también la literatura, le repliqué. A esta pertenecen las obras de ingenio y la presente pudiera mirarse como perfecto modelo en ese ramo. El crítico de mi huésped me respondió. Verdades prácticas, señor mío, asuntos de pública utilidad, como los que veo en el número 2 del mismo periódico y esperamos ver en lo sucesivo. Al lado de éstas me parecen las Ruinas lo mismo que el ciprés de que habla el poeta, pintado en el lienzo del náufrago. Las bellezas de semejante composición, estarian bien empleadas con algún provecho tratando el mismo argumento de una manera científica y más propia del instituto de la sociedad. ¡Cuánta materia of recen los restos de Pachacamac a las investigaciones del filósofo, del geómetra, del arquitecto, del anticuario! con ellas acaso habría abierto nuestro autor el camino a útiles descubrimientos, y a noticias en que se interesase el bien común. Escribase lo que se quiera, pero sin olvidar nunca que la obra no será perfecta, mientras no se consiga unir en ella la utilidad con el agrado.

Nada pude oponer a estas reflexiones que me parecieron juiciosas, y mi silencio puso fin a la conversación. Querria, señor editor, que las expusiese $V$. al examen de otros inteligentes, dándolas a luz; y de no, haga de ellas el uso que más tenga por conveniente. Soy de V. su apasionado.

JUSTO AgRíCOLA.

\section{ANEJO No 3}

De El Sol del Perú, Lima, No 4, t2 de abril de I822, págs. 3-4 ("Respuesta al Censor de las Ruinas de Pachacamac") y del Correo Mercantil, Político y Literario, Lima, № 23, 24 de abril de I822, págs. 2-5 ("Artículo remitido.-Respuesta al Censor de las Ruinas de Pachacamac: ilustrada con notas").

Respuesta al Censor de las Ruinas de Pacbacanac; ilustrada con notas. 
La crítica hecha con urbanidad es útil porque perfecciona el ingenio y los modales; ${ }^{1}$ mas el desempeñarla con acierto pide gusto y mucha instrucción por ser de las cosas más difíciles en literatura. Permítaseme decir que el que ha censurado las ruinas de Pachacamac acredita tener ideas muy circunscriptas. ${ }^{2}$ Me acusa de plagiario de Volney. ${ }^{3}$ Educado en modelos infinitamente superiores a este autor sé lo que pesan en la estimación de los sabios sus viajes a la Siria y su cuadro de la América del Norte. No son de este precio las Ruinas de Palmira, que bajo de un estilo lastimero, como decían los antiguos españoles, introducen en la juventud sin luces, nociones inexactas.

Pero aun cuando lo hubiese tomado por modelo, esto no es ser plagiario. Virgilio imitó a Homero, Horacio a Píndaro, Cicerón a Demóste nes, y los Padres del gusto latino han servido luego de ejemplar a los sabios que les han seguido. $\mathrm{Ni}$ se toman los solos planes; entran en la imitación las figuras, los tornos y aun las palabras, ${ }^{\circ}$ porque tal es la excelencia de un escritor, enriquecer su nativo lenguaje con los despojos de los extranjeros y peregrinos.

A este objeto miraba el precepto de Horacio, vox exemplaria Graeca, nocturna versate manu versata diuma. Nuestro censor parece que hace bastante aprecio de este poeta filósofo, mas no ha percibido su sal y delicadeza, si le hemos de juzgar por el verso que cita. Purpureus late qui splendeat unus et alter panmus. Suprimiendo la voz assuitur le ha quitado al verso la armonía por falta de medida, ${ }^{6}$ y el placer que hace

1 ¿Si será de esta especie la respuesta que reimprimimos? Dígalo la cláusula inmediata, y ottras más.

2. No lo serán tanto que no bastasen a conocer lo bueno que hay en las Rui. nas y que se elogia en la misma censura; o deberá convenir el autor de ellas en que su mérito es muy poca cosa, cuando está al alcance de ideas muy circunscriptas.

3 Perdone el señor académico. El censor se explicó de esta manera: No falta quienes pretendan rebajarle el mérito con esparcir que es un plagio de Volney. No divé yo otro tanto.-Injusticia es imputarle lo que no afirma y sólo refiere como juicio de otros. Véase la carta de Justo Agrícola en el número 21 de este periódico.

4 Estamos de acuerdo.- ¿Por qué pues nuestro autor se da por agraviado de una censura en que se le alaba de perfecto imitador?

5 Pero no tan servilmente como en las Ruinas de Pacbacamac, dijo un chusco que of́a leer este pasaje.

6 ¿No podría disimularse este defecto a quien tiene ideas muy circunscriptas, y no se ha educado como el señor académico, en Modelos infinitamente superiores a Volney? Pues quede con esta crítica hecha con urbanidad, bien escarmentado. Aprenda de este erudito a percibir la sal y delicadeza de los poetas, mejor que los escritores que citan frecuentemente versos tíuncos del modo más adaptable al intento; y sépase que ni es lícito acomodar en la oración un emistiquio, por no quitar al terso la armonia por falla de medida, y el placer que bace saltar la imagen del costurón, si es que en el verso entero haya imagen de costurones. 
saltar la imagen del costurón que reúne entre sí paños viejos y nuevos para formar un ropaje ridículo.7

Todos los escritores de la antigüedad están llenos de descripciones, pinturas y lamentaciones de ruinas y de apariciones de genios y fantasmas, ${ }^{8}$ porque en lo triste y asombroso están las fuentes del verdadero sublime. ${ }^{9}$ Cuando se recuerda la monarquía de los Incas, no es para que ellos resuciten de sus huacas; ni los ilustrados pueblos que hoy tiene el Perú retrocedan a las primitivas ideas de los hombres ignorantes. Era una figura que debía hacer alta impresión para amar la libertad; pues no se puede recordar el gobierno pacífico y moderado de los antiguos indios sin llenarse de indignación con la memoria de los atroces vándalos que se cebaron en sus bienes y los despojaron de la libertad y del imperio; y en consecuencia no sé si podría decirse cosa más útil al fin que nos proponemos. Restaurado uno y otro por el genio protector, la sabiduría de los hombres que han de representar los pueblos, designará la forma de gobierno más conveniente. Yo no tomo parte en ella: he oído discurrir en la academia con bastante erudición por los que siguen opiniones diversas, más a mí aún me quedan otras ideas que no se han producido. Cicerón, el padre de la $\mathrm{Re}^{-}$ pública Romana, juzgaba que el mejor gobierno sería a quel que se compusiera del monárquico, aristocrático y democrático moderadamente atempe-

7 Horacio compara la importunidad de bellas descripciones esparcidas en una obra a retazos brillantes que se zurciesen a un vestido. No dice si viejo o nuevo: que tanto el uno como el otro puede hacerse ridículo con retazos que desdigan; ni menos que estén groseramente cosidos, significado propio y único de la palabra costurón.

8 Fácil recurso que les ministraba su mitología, especialmente para desenlace del nudo en el drama y la epopeya. Seguir este ejemplo no es reprensible en las composiciones poéticas, como sea con la decencia y dignidad que se ve observada en las Ruinas. En esta parte no se les ha censurado; y así está por demás la apología.

\% Quisiéramos que se explicase algo más claro. iSe hermanan bien o son una misma cosa lo triste y lo asombroso, como parece que da a entender el autor en el modo con que se expresa? ¿La admiración, o el terror y espanto (que esto significa asombro) produce impresiones de tristeza? ¿En esto y no más están las fuentes del verdadero sublime? $Y$ entonces ¿qué vendrá a ser de tantas inágenes y pensamientos, ya risueños y alegres, ya heroicos, ya tiernos, ya también festivos, ya finalmente animados de las demás pasiones que emplea la elocuencia, todos los cuales sorprenden y arrebatan al alma por su grandiosidad y energía? Sin duda se engañan los buenos conocedores de exquisito gusto que los tienen por sublimes, y mucho más se engañaron los maestros del arte de decir, cuando observan con Longino que lo patético no es constitutivo esencial de lo sublime, y que uno y otro son cosas muy diversas, aunque suelen andar juntos y muchas veces se confunden; de manera, que no siempre es sublime la expresión de las pasiones, y al contrario, gran parte de los rasgos sublimes con que se hacen admirar los modelos infinitamente superiores en que nuestro autor está educado, lo son sin emplearse en ellos to patético, que entonces no sería oportuno. Bórtense pues todas las observaciones y preceptos que hay sobre la materia, y en su lugar pondremos el que aquí nos enseña a entender estos asuntos. 
rados; por el contrario, el severo Tácito creía inverificable semejante proyecto, y en caso de realizarse, de poca duración, y se inclinaba al régimen republicano. ¿Por qué pues un hombre como Cicerón que debió su gloria y esplendor a la república, y la gobernó con tanto acierto, opinaba a favor del gobierno mixto, y Tácito que vivió con tanto aprecio bajo el imperio quería el republicano? Yo dejo este problema a que lo resuelva el censor de las Ruinas de Pachacamac y otros grandes genios como el suyo. ${ }^{10}$ Por mi parte sigo en todo a Platón, que decía que el primer cuidado de los pueblos debía ser que mandase la ley y fuese obedecida desde el primero hasta el último de la Sociedad; porque ¿qué importará al bien de ella, el que mande uno o muchos, si la ley no se obedece? En este caso cada una de estas formas de gobiernos degenerará en los vicios que le están anejos. Pueblos del Perú, ¿queréis ser felices en vuestra regeneración? Estableced leyes que conduzcan a verificarlo, y dadles tal vigor, que nadie pueda quebrantarlas sin que quede sujeto a las penas por ellas impuestas. Este debe ser vuestro esmero, y es vuestro primer deber.

En el empeño de censurar la Ruinas de Pachacamac pretende el que lo ejecuta que en dándose verdades sólidas le agradarian en estilo bumilde, y a eso se atiene. 11 . Pero mi buen amigo esto es el bumi repit de Horacio, ${ }^{12}$ que procura citar tan a menudo. El desaliño y arrastrarse por los suelos, es propio de los tiempos bárbaros; y si V. no ha nacido para dar nuevas leyes al género humano, tiene contra sí a todos los grandes maes-

to Retos al aire. El que escribió la censura no precia de grande genio; y en ella dijo bien claramente que no es político, y que debe prescindir de estas materias. La resolución de semejantes problemas corresponde al sabio a quien aun quedan ottas ideas que no se ban producido en las discusiones de la academia. Cuando las produzca, veremos de qué manera el imperio de los Incas va a renacer más glorioso y brillante, problema cuya resolución nos interesa más que inquirir las ideas políticas de Cicerón y de Tácito; y debe darnos las pruebas quien anunció el aserto.

ذ1 Mi buen amigo, un poquito de más fidelidad. He aquí lo que dijo el Censor: Déme $V$. obras que me enseñen verdades y sólidas doctrinas, aunque sea en estilo familiar $y$ bumilde; ya éstas me atengo. Esto es muy diverso. Trastornar el sentido de palabras ajenas es algo más que omitir en un verso latino alguna voz que no hace falta al intento a que se quiso aplicar. Pero ¿qué mucho? ¿Quién creería que el empeño de responder a la censura, ofuscase a un literato educado en modelos infinitamente superiores a Volney, hasta el punto de confundir el estilo familiar y humilde con el desaliñado que se arrastra por los suelos? Sus conocimientos y delicado gusto en bellas letras son muy notorios para que no atribuyamos a designio voluntario de wrbanidad estas equivocaciones que en otro cualquiera se. rían efecto de ignorancia.

12 Serpit bumi, dijo Horacio, mi buen amigo. ¿V. que sabe percibir tan bien la sal y delicadeza del poeta, pudo alucinarse hasta levantarle un tesímonio como éste, sin duda más culpable que citarle con una palabra de menos? ¿Y sı oído tan delicado pudo acomodarse con el perverso sonido y con el garrafal error que atribuye al mismo poeta y que habría en principiar el verso con un jambo cual es Humi? Mi buen amigo, no hay que fiarse tanto de la memoria. 
tros del arte de escribir. Si quiere cosas perceptibles al vulgo más rudo en estilo ramplón, ${ }^{13}$ váyase norabuena con él a las escuelas, adonde podrá deletrear el catón y otros libros dedicados a los que no tienen la razón bien formada, que traen grandes verdades en religión y política. Pero querer en el gusto del siglo, y a nombre de una Sociedad, que se escriba en estilo bajo y humilde, no lo ha pensado ningún hombre de buen sentido, ni en los tiempos antiguos, ni en los modernos. El estilo de las composiciones literarias es lo mismo que los rostros en los seres humanos, cuando éstos están limpios y aliñados y con agradables contornos atraen imperiosamente el ánimo del que los mira; por el contrario los sucios, descuidados, y de facciones desagradables los repelen con fuerza. ${ }^{14}$ De allí es el sumo cuidado con que Aristóteles, Longino, Cicerón, Horacio, Pope, Boileau y otros hombres de exquisito gusto, han tratado con sumo esmero el dar reglas para perfeccionar el estilo. ${ }^{15} \mathrm{Y}$ persuadirse a que haya un papel escrito con elegancia sin que traiga utilidad alguna, es no entender estos asuntos, pues cuando no incluyan en su totalidad los partos del entendimiento, llevarán consigo las graciosas pinturas de la imaginación; ;it y es de esencia de todos los buenos periódicos, como lo fue el Mercurio Peruano, mezclar unos con otros para seguir el prudente consejo de Horacio qui miscuit utile dulci, lectorem delectando, poriterque monendo.

13 Otro rasgo de urbanidad. Sin duda que la respuesta será muy zutil para perfeccionar el ingenio y las modales. Lo que el Censor quiere es que no insista. mos en obras de puro deleite por su elegancia poética pero de ninguna solidez, y que se prefieran las instructivas, las de asuntos prácticos, aunque escritas familiarmente, de modo que las entiendan hasta los ignorantes; mas no pretende que las verdades se deban proponer en el lenguaje de los mercados. Bien sabe el autor de la respuesta que el estilo familiar es bumilde y sencillo, porque catece de elevación y ornatos, sin ser por eso incorrecto, grosero y demasiado humilde o ramplón; porque guarda el decoro de la elocuencia que se acomoda muchas veces con lo llano, pero jamás con lo plebeyo. Mucha elevación requiere la tragedia; y sin embargo no se desdeña en ocasiones de ese lenguaje familiar y humilde. Et tragicus plerumque dolet sermone pedestri, dijo Horacio, a quien citaremos siempre, aunque desagrade a nuestro sabio, pues nunca será demasiado recurrir en estas materias a los preceptos de su arte poético, llamado justamente el código del buen gusto.

14 También la natural hermosura de las facciones resalta más desdeñando la afectación de prestados adornos, mientras el rostro sin agradables contornos suele parecer más deforme con el demasiado aliño; y el poner todo el mérito de una obra únicamente en el ornato y pompa de la composición, lo compara Cicerón al ridículo empeño de quien buscase donaire de talle y hermosa presencia en donde no hubiese cuerpo.

$15 \mathrm{Y}$ entre ellas dieron muchas para el que nuestro autor llama desaliñado y ramplón, a fin de que sea sencillo y familiar sin ser descuidado ni indecente, y no se apropie adornos que no le corresponden.

16 ¿Conque un papel escrito con elegancia, aunque en él no tenga parte el entendimiento, es de alguna utilidad, porque lleva consigo las graciosas pinturas de la imaginación? Seguramente el que lo dijo quedará satisfecho. 